\section{Soil Temperature Mediated Seedling Emergence and Field Establishment in Bentgrass Species and Cultivars during Spring in the Northeastern United States}

\author{
J. Scott Ebdon ${ }^{1}$ and Michelle DaCosta ${ }^{1}$
}

ADDITIONAL INDEX WORDs. golf greens, renovation, seeding rate, turfgrass

SUMMARY. Reestablishment of damaged golf greens and fairways planted to creeping bentgrass (Agrostis stolonifera), colonial bentgrass (A. capillaris), and velvet bentgrass $(A$. canina $)$ is a common practice following winter injuries. Identifying bentgrass species (Agrostis sp.) and cultivars with the potential to establish under low soil temperatures would be beneficial to achieving more mature stands earlier in the spring. Twelve bentgrass cultivars, including seven cultivars of creeping bentgrass (007, 13-M, Declaration, L-93, Memorial, Penncross, and T-1), two colonial bentgrass cultivars (Capri and Tiger II), and three velvet bentgrass cultivars (Greenwich, SR-7200, and Villa), along with 'Barbeta' perennial ryegrass (Lolium perenne) were evaluated for grass cover in the field during early spring. Bentgrass species and cultivars were seeded in the field at the same seed count per unit area. Soil temperatures were monitored in unseeded check plots from initial planting date on 8 Apr. to termination on 29 May 2013. Soil temperatures increased linearly during the 52-day experimental period from 4.7 to $23.5^{\circ} \mathrm{C}$. All species and cultivars emerged at $\approx 10^{\circ} \mathrm{C}$ soil temperature. Bentgrass species and cultivars varied only 2 to 3 days in their initial seedling emergence, while days varied among bentgrasses from 5.5 days (to $10 \%$ cover) to 8.6 days (to $90 \%$ cover). All velvet bentgrass cultivars required higher soil temperatures $\left(13.6^{\circ} \mathrm{C}\right)$ and more time $(26$ days $)$ following initial seedling emergence to establish to $90 \%$ cover in the early spring. Creeping bentgrass cultivars 007, 13-M, and Memorial, along with colonial bentgrass cultivars Capri and Tiger II, were statistically equal to 'Barbeta' perennial ryegrass in their capacity after seedling emergence to achieve faster cover at lower soil temperatures. Heavier (larger) bentgrass seed was associated with faster cover during the early stages of establishment, but seed size was uncorrelated with establishment during later stages from $50 \%$ to $90 \%$ cover.

$\mathrm{G}$ olf greens and fairways planted to creeping bentgrass (Agrostis stolonifera $)$, colonial bentgrass (A. capillaris), and velvet bentgrass $(A$. canina) require overseeding to reestablishment areas damaged from winter injuries. Cold soil temperatures $\left(\approx 10^{\circ} \mathrm{C}\right)$ typical of early spring plantings in the northern United States reduce seed germination and establishment vigor of cool-season grasses when compared with more favorable

Received for publication 21 May 2020. Accepted for publication 27 Oct. 2020.

Published online 8 December 2020.

${ }^{1}$ Stockbridge School of Agriculture, Paige Laboratory, University of Massachusetts, Amherst, MA 01003

J.S.E. is a Professor.

M.D. is an Associate Professor.

J.S.E. is the corresponding author. E-mail: sebdon@ umass.edu.

This is an open access article distributed under the CC BY-NC-ND license (https://creativecommons.org/ licenses/by-nc-nd/4.0/).

https://doi.org/10.21273/HORTTECH04653-20 soil temperatures of 20 to $30{ }^{\circ} \mathrm{C}(\mathrm{He}$ et al., 2013; Liu et al., 2001; McGinnies, 1960; Wright et al., 1978). Delayed growth shortens the growing period of seedling grasses and results in lower plant numbers in turf stands (Larsen et al., 2004), which are more susceptible to competition for moisture and summer drought (Young and Evans, 1982) and to competition from weeds during the establishment phase (Murphy et al., 2005).
Seed germination is the initial step in establishment, and rapid establishment can mitigate costs and revenue loss when golf courses openings are delayed. High-quality seed and seedling vigor is characterized by high viability (more germinating seeds). Emergence is the point that the primary leaf emerges from the soil surface followed by growth and development of roots, stolons, and rhizomes to form a dense turf. Seedling emergence, seedling vigor, and mature plant growth are distinct but related stages. Numerous studies have investigated laboratory seed germination characteristics such as final germination percentage and mean germination times that are conducted under controlled temperatures and moisture. It has been suggested the rate of growth after emergence is determined largely by the genotype and environment and not by the rate of seed germination (Argerich et al., 1990; Scott and Jones, 1985; Yamamoto et al., 1997a). For example, Yamamoto et al. (1997b) found the rate of emergence of the second and third leaves in kentucky bluegrass ( $\mathrm{Poa}$ pratensis) to be under genetic control.

Unlike controlled environments, seeds are exposed to variable and unfavorable temperature and soil moisture in the field that delay and postpone germination, thereby affecting establishment (Happ et al., 1993). Germination of rough bluegrass (Poa trivialis) in the growth chamber at $10{ }^{\circ} \mathrm{C}$ provided two to three times the germination rate observed in the field when rough bluegrass was over-seeded into hybrid bermudagrass (Cynodon dactylon $\times$ C. transvaalensis) putting greens (Liu et al., 2001). Emergence of perennial ryegrass (Lolium perenne) seeded on compacted soil cores was only $40 \%$ to $69 \%$ of that observed

\begin{tabular}{llll}
\hline $\begin{array}{l}\text { Units } \\
\begin{array}{l}\text { To convert U.S. to SI, } \\
\text { multiply by }\end{array}\end{array}$ & U.S. unit & SI unit & $\begin{array}{l}\text { To convert SI to U.S., } \\
\text { multiply by }\end{array}$ \\
\hline 0.3048 & $\mathrm{ft}$ & $\mathrm{m}$ & 3.2808 \\
0.0929 & $\mathrm{ft}^{2}$ & $\mathrm{~m}^{2}$ & 10.7639 \\
2.54 & inch $(\mathrm{es})$ & $\mathrm{cm}$ & 0.3937 \\
4.8824 & $1 \mathrm{~b} / 1000 \mathrm{ft}^{2}$ & $\mathrm{~g} \cdot \mathrm{m}^{-2}$ & 0.2048 \\
1.1209 & $\mathrm{~b} / \mathrm{acre}$ & $\mathrm{kg} \cdot \mathrm{ha}^{-1}$ & 0.8922 \\
28.3495 & $\mathrm{oz}$ & $\mathrm{g}$ & 0.0353 \\
28,350 & $\mathrm{oz}$ & $\mathrm{mg}$ & $3.5274 \times 10^{-5}$ \\
305.1517 & $\mathrm{oz} / \mathrm{ft}^{2}$ & $\mathrm{~g} \cdot \mathrm{m}^{-2}$ & 0.0033 \\
$\left({ }^{\circ} \mathrm{F}-32\right) \div 1.8$ & ${ }^{\circ} \mathrm{F}$ & ${ }^{\circ} \mathrm{C}$ & $\left({ }^{\circ} \mathrm{C} \times 1.8\right)+32$
\end{tabular}


under optimal germination when assayed on moist paper (Snapp et al., 2008). Total emergence and emergence rates in the field have been shown to be lower than emergence responses in the laboratory for coolseason range grasses (Hardegree and Van Vactor, 2000). These same authors reported greater germination in laboratory tests than measured in the field during early spring planting dates. Laycock and Shildrick (1979), however, found some positive correlation between perennial ryegrass laboratory germination and initial establishment measured in the field during the time between the sowing date (seed germination and emergence phase) and before the first mowing (maturity).

Soil temperature, water potential, and oxygen levels are important environmental factors affecting seed germination and influencing the seedlings to emerge from the soil (Burris, 1976; Pollock, 1972; Powell, 1988). Beard (1979) found the base temperatures $(\mathrm{Tb})$, below which no germination is observed, to $\mathrm{be} \approx 7^{\circ} \mathrm{C}$ for perennial ryegrass and $11{ }^{\circ} \mathrm{C}$ for creeping bentgrass. Trudgill et al. (2000) reported colonial bentgrass $\mathrm{Tb}$ of $8{ }^{\circ} \mathrm{C}$, and perennial ryegrass exhibited a $\mathrm{Tb}$ of $5^{\circ} \mathrm{C}$. The final stage of establishment involves mature roots, shoots, and lateral stems to form, which is a distinctly different phase from seed germination and emergence (Beard, 1973). As such, constant temperature and moisture regimes typical of germination laboratory tests are not necessarily predictive of field performance (Steiner et al., 1989; Trawatha et al., 1990).

Seed requires an accumulation of time and temperature ("thermal-time") above $\mathrm{Tb}$ to germinate (Larsen and Bibby, 2005; Larsen et al., 2004) and in turn, to establish. Nonlinear regression thermal-time models have been used for seed germination and emergence (Larsen and Bibby, 2005; Larsen et al., 2004; Zhang et al., 2013). Monitoring soil temperatures after seedling emergence in the field until a mature stand is formed (i.e., requiring frequent mowing) has not been investigated in bentgrass species (Agrostis sp.) and cultivars. Growing degree day (GDD) models have been computed using soil or air temperatures collected daily. Base temperature varies with the crop with GDD for warm-season turfgrass establishment calculated using $\mathrm{Tb}$ close to $5^{\circ} \mathrm{C}$ (Frank et al., 1998; Patton et al., 2004; Shahba and Qian, 2008; Unruh et al., 1996), while for cool-season lawn grass species, values of $\mathrm{Tb}$ for seed germination ranged from 1.6 to $3.6^{\circ} \mathrm{C}$ (Larsen and Bibby, 2005), with bentgrass species exhibiting $\mathrm{Tb}$ closer to $10^{\circ} \mathrm{C}$ (Heineck et al., 2018; Trudgill et al., 2000).

Identifying bentgrass species and cultivars with the potential to establish under low soil temperatures would be beneficial toward achieving more mature stands earlier in the spring. Simulated field-temperature studies have been conducted in coolseason range grasses (Hardegree and Van Vactor, 1999), cool-season lawn grasses (Larsen and Bibby, 2005), and in cool-season turfgrass for golf use such as bentgrass species and cultivars (Heineck et al., 2018). However, these responses were not validated in the field. Subsequently, Hardegree and Van Vactor (2000) reevaluated their previous findings and found simulated soil temperature models predicted greater germination than measured in the field, and they reported total emergence in the field to be more variable. While bentgrass species and cultivars have been tested in laboratory settings, there is a need to study cold temperature germination of these grasses in the field. Our research objective was to identify bentgrass species and cultivars with the capacity to establish to maturity in the shortest time and under cooler soil temperatures during an early spring planting date.

\section{Materials and methods}

The study was conducted on a Hadley silt loam (coarse-silty, mixed, superactive, nonacid, mesic Typic Udifluvents) located at the Joseph Troll Turf Research and Education Center at the University of Massachusetts Amherst in South Deerfield, MA. The Hadley silt-loam soil is characterized as $23.5 \%$ sand, $63.8 \%$ silt, and $12.7 \%$ clay. A field study was prepared and planted on 8 Apr. 2013 to assess germination vigor and percent grass cover during establishment. Twelve bentgrasses, including seven cultivars of creeping bentgrass (007, 13-M, Declaration, L-93, Memorial, Penncross, T-1), two cultivars of colonial bentgrass (Capri, Tiger II), and three cultivars of velvet bentgrass (Greenwich, SR7200 , Villa), were selected. All seed was fresh seed (harvested from 2012) and planted within 1 year of the test date.

Seeding rates were adjusted using seed count and germination rate (Table 1) to deliver the same approximate live seed per unit area to $3-\times 3$ $\mathrm{ft}$ plots, which also corresponded to the typical seeding rate for bentgrass species. Seed weight was determined for each of the 12 bentgrass species and cultivars by counting and weighing three replicates of 100 seeds. Seed germination was determined on seed following surface sterilization using 95\% ethanol and $2 \%$ sodium hypochlorite solution, and then storing these at $5{ }^{\circ} \mathrm{C}$ before germination tests. Sterilized seed was placed in petri dishes containing moistened filter paper. The germination test was conducted with two replicates using petri dishes seeded with 50 seeds of a single cultivar, used as experiential units. Petri dishes were placed in a growth chamber under an 8-h photoperiod and low light levels (photosynthetic photon flux density of $\approx 60$ $\left.\mu \mathrm{mol} \cdot \mathrm{m}^{-2} \cdot \mathrm{s}^{-1}\right)$. Distilled water was applied as necessary to prevent filter paper and seed from drying out, and dishes were rotated to minimize any chamber effects. Germination temperature was set to $25^{\circ} \mathrm{C}$, with final germination recorded daily for up to $2 \mathrm{l}$, or until maximum germination percentage was reached and no additional germination was observed. Seed germination was based on the emergence of a visible shoot.

Plots were seeded to bare-soil by hand immediately after ground thaw and when the ground could be properly prepared for planting. Before seeding, plots were tilled and weeds were removed. Plots were planted as a randomized complete block design using three replicates. 'Barbeta' perennial ryegrass was also included as part of the field test as a reference species because of its rapid germination and establishment rate. Bentgrass plots were not mowed during the establishment period until a total plant height of $1 / 2$ inch was achieved. Thereafter, all bentgrass plots were mowed three times per week at a 3/8-inch height of cut with lightweight (walk-behind) reel mowers, with clippings collected. Perennial ryegrass check plots were mowed weekly at 
Table 1. Seed characteristics for bentgrass species and cultivars.

\begin{tabular}{|c|c|c|c|c|}
\hline Species-cultivar & Seeds $(\text { no. } / g)^{\mathrm{z}}$ & Seed wt $(\mathrm{mg} / 100 \text { seeds })^{\mathrm{y}}$ & Germination $(\%)^{x}$ & Adjusted seeding rate $\left(\mathrm{g} \cdot \mathrm{m}^{-2}\right)^{\mathrm{w}}$ \\
\hline 007 & $13,210(411)$ & $7.57(0.23)$ & $94.0(4.2)$ & 2.50 \\
\hline Declaration & $11,025(974)$ & $9.07(0.80)$ & $92.0(2.8)$ & 3.06 \\
\hline $\mathrm{L}-93$ & $12,771(248)$ & $7.83(0.15)$ & $94.0(2.8)$ & 2.58 \\
\hline Memorial & $13,699(1137)$ & $7.30(0.31)$ & $92.0(2.8)$ & 2.46 \\
\hline \multicolumn{5}{|l|}{ Velvet bentgrass } \\
\hline Greenwich & $17,544(308)$ & $5.70(0.10)$ & $95.0(1.4)$ & 1.86 \\
\hline SR-7200 & $14,085(703)$ & $7.10(0.36)$ & $82.0(1.4)$ & 2.68 \\
\hline Villa & $19,493(1186)$ & $5.13(0.31)$ & $90.0(2.8)$ & 1.77 \\
\hline \multicolumn{5}{|l|}{ Colonial bentgrass } \\
\hline
\end{tabular}

${ }^{\mathrm{z}} 1$ seed $/ \mathrm{g}=28.3495$ seeds $/ \mathrm{oz}$

${ }^{\mathrm{y}}$ Average weight of three replicates of 100 seeds; $1 \mathrm{mg}=3.5274 \times 10^{-5} \mathrm{oz}$.

${ }^{\mathrm{x}}$ Germination percentage of two replicates of 50 seeds germinated for $21 \mathrm{~d}$ at $25^{\circ} \mathrm{C}\left(77.0{ }^{\circ} \mathrm{F}\right)$.

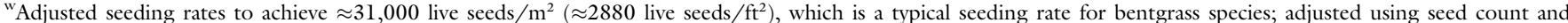
germination rate to standardize all bentgrass species and cultivars to the same number of live seeds per unit area; $1 \mathrm{~g} \cdot \mathrm{m}^{-2}=0.0033 \mathrm{oz} / \mathrm{ft}^{2}$.

a 2 -inch height of cut using rotary mowers, with clippings collected.

Initial seedling (coleoptile) emergence was recorded daily. Grass cover during establishment was recorded on a 2- to 6-d interval until 29 May 2013. Grass cover was measured using an intersect grid. The length and width of the grid measured the same as the length and width of the main plots $(3 \times 3 \mathrm{ft})$ and formed $100(10 \times 10)$ intersects. Therefore, counts were based on a total number of 100 intersects calculated as percent green cover. Cover was indirectly measured using canopy reflectance indices with a multispectral radiometer (CropScan, Rochester, MN). These indices provide indirect measures of turfgrass canopy properties such as color and biomass, and they have shown good correlations with response to various agronomic practices and stresses (Jiang, 2008; Johnsen et al., 2009; Lee et al., 2011). Measurements were taken about around the same time $(1$ to $3 \mathrm{~d}$ ) of visual grass cover, using the intersect grid, but only on clear, sunny days between 1100 and 1300 HR. Normalized difference vegetation index (NDVI) was used to estimate aboveground green biomass and was calculated using the reflectance $(\mathrm{R})$ of wavelengths in the red and near IR regions, including 660 and $940 \mathrm{~nm}$, and calculated as follows: (R940 - R660)/(R940 + R660).
No protective covers were used at the time of planting so that initial emergence as well as visual estimates of weekly grass cover could be effectively assessed. Irrigation was applied as needed to maintain adequate soil moisture for germination. Soil $\mathrm{pH}$ according to soil test results was $\mathbf{5 . 5}$ before planting, with soil phosphorus $(\mathrm{P})$ and potassium $(\mathrm{K})$ to be mediumhigh and high, respectively. After all plots had shown initial emergence, $18 \mathrm{~N}-10.5 \mathrm{P}-4.2 \mathrm{~K}$ fertilizer was applied at $0.5 \mathrm{lb} / 1000 \mathrm{ft}^{2} \mathrm{P}$ as recommended by soil test results. Siduron (Tupersan; PBI Gordan, Shawnee, KS) was applied on 14 May 2013 at $4 \mathrm{lb} /$ acre a.i. for preventative control of annual grassy weeds.

Temperature probes were installed in two adjacent, nonseeded check plots to record soil surface temperatures at a $1 / 2$-inch soil depth. Soil temperatures were recorded throughout the experimental period, from the time when plots were initially planted until termination of the study on 29 May 2013. Soil temperature was recorded every 10 min but was averaged daily. In addition, GDD were computed using soil temperatures collected daily and averaged over a 24-h period. The general equation for GDD was $[($ maximum + minimum $) /$ 2] - Tb.

A four-parameter sigmoidal (nonlinear regression) model was used to curve fit the cover data (SigmaPlot version 14; Systat Software, San Jose, CA). The general equation was

$$
\mathrm{y}=\mathrm{y} 0+\mathrm{a} /[1+\exp (-(\mathrm{x}-\mathrm{x} 0) / \mathrm{b})],
$$

where $y=$ percent cover; $y 0=$ lower asymptote of $y$ on the curve; $x 0=$ the midpoint value for $x$ (inflection point) between the upper and lower asymptote of the curve; $a=$ upper asymptote for $y$ on the curve; $b=$ slope at the inflection point for $x 0$ or the difference in $x$-values between $75 \%$ and $25 \%$ of the amplitude. Two data sets (i.e., $x$-variables) were fitted using the sigmoidal model described previously, with 1 ) the value for $x$ as time (days) after emergence was used to compute $y$, and 2) the value $x$ using the soil temperature average monitored in the check was used to compute $y$ in the above equation. In both cases, the same percent cover was used. At initial seedling emergence (Table 2), time (days) as the independent variable $x$ was " 0 ," and cover as the response variable $y$ was assumed to be about " 0 ". Thereafter, response- $y$ and independent- $x$ variables were equal to measured cover at its corresponding time (days) of measurement. Similarly, initial soil temperature average at emergence was $x$ as reported in Table 2 , and the response variable $y$ as cover was " 0 ," with response- $y$ and independent- $x$ variables thereafter equal to measured cover at its corresponding soil temperature average recorded in check 


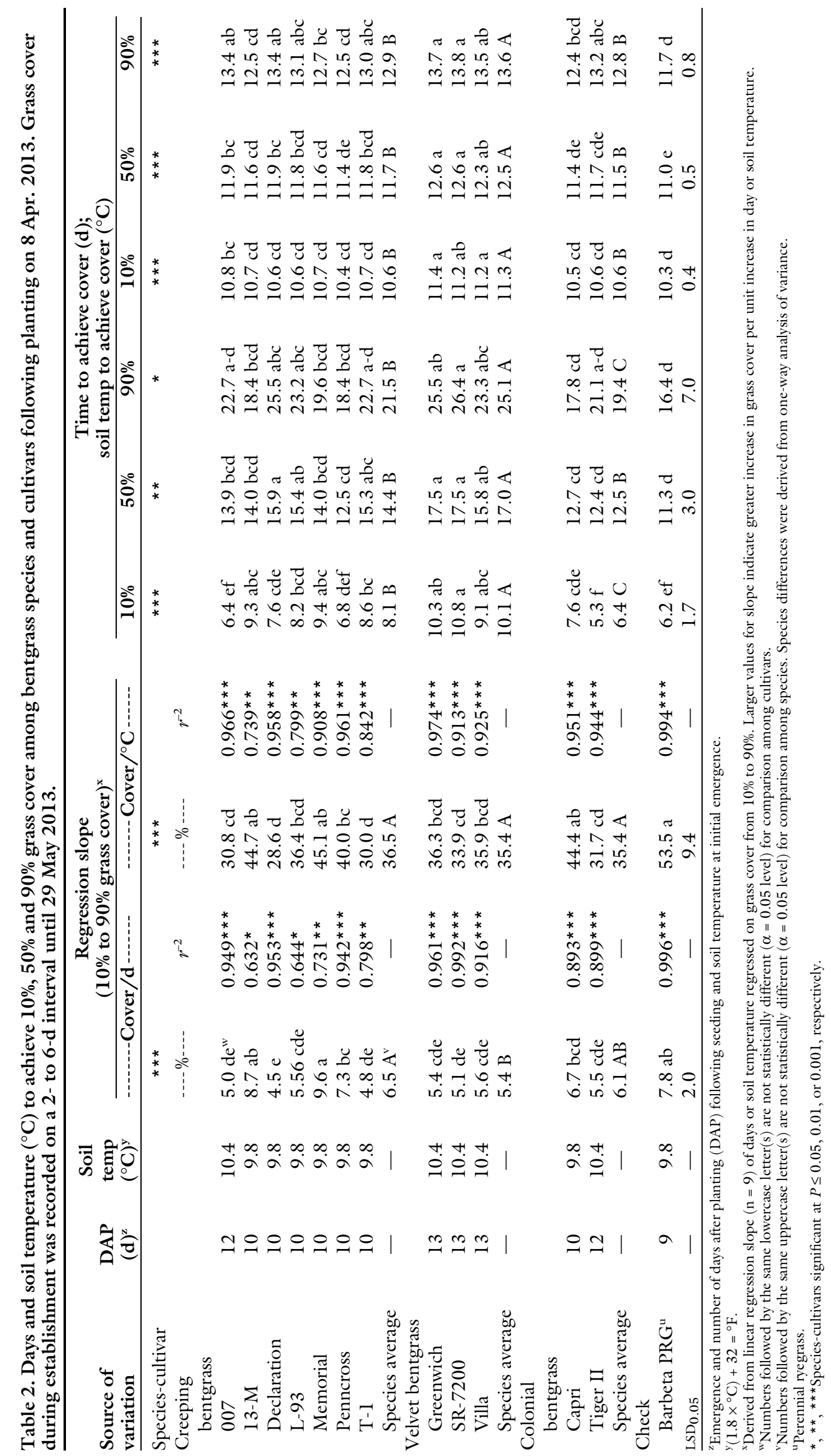




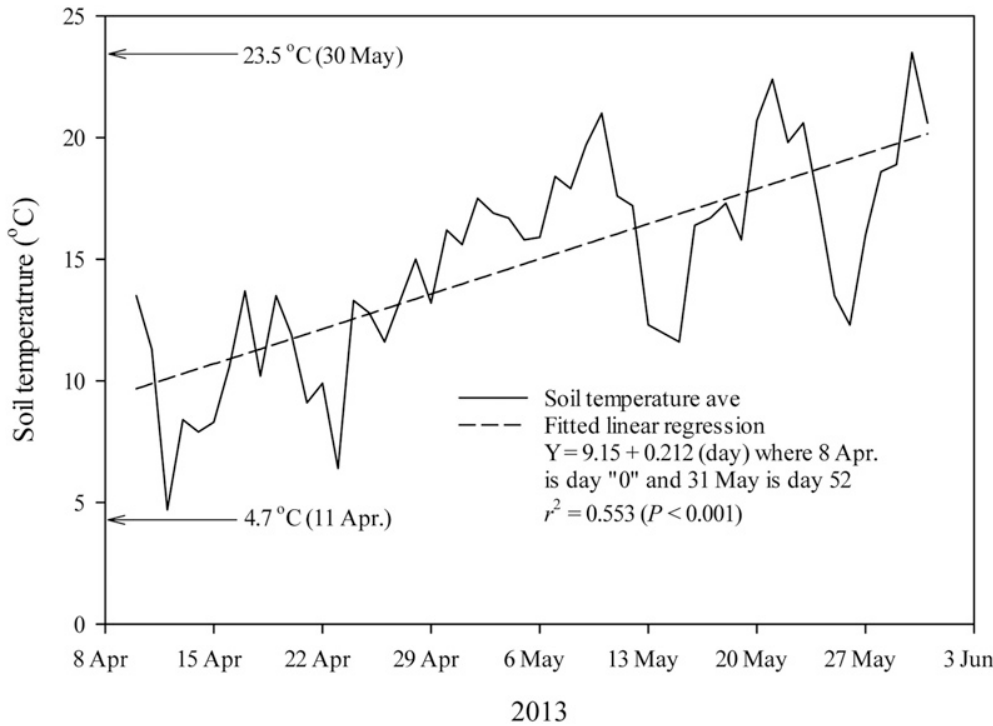

Fig. 1. Daily soil temperature average recorded during the experimental period. Soil sensors were imbedded near the soil surface $[1 / 2$-inch $(1.27-\mathrm{cm})$ soil depth] in unseeded check plots. Soil temperatures ranged from 4.7 to $23.5{ }^{\circ} \mathrm{C}$ during 52 $\mathrm{d}$ following planting on 8 Apr. 2013; $\left(1.8 \times{ }^{\circ} \mathrm{C}\right)+32={ }^{\circ} \mathrm{F}$.

plots. Measurements for $y$ as cover and $x$ as time (days) after emergence or soil temperature averages were recorded until 29 May 2013. In total, $11 \mathrm{~d}$ or soil temperature averages and their corresponding cover for each plot (experimental unit) were used to fit the data according to the above sigmoidal model and to compute the associated parameters $y 0, x 0, a$, and $b$. Following curve fitting, time (days) or soil temperatures to achieve $10 \%, 50 \%$, and $90 \%$ cover was determined by back calculation using fitted sigmoidal parameters.

Calculated days or soil temperatures between $10 \%$ to $90 \%$ cover follow a linear trend on the sigmoidal curve, and therefore linear regression slopes were calculated for each experimental plot to determine grass cover per unit day or grass cover per unit ${ }^{\circ} \mathrm{C}$ using simple linear regression. Slope estimates serve as indicators for the rate of grass establishment. Higher slope estimates per unit day indicated faster grass cover per day from $10 \%$ to $90 \%$ cover, while higher slope estimates per unit ${ }^{\circ} \mathrm{C}$ indicated greater capacity for cover during establishment from $10 \%$ to $90 \%$ cover under the cooler soil conditions in early spring.

Data including slope estimates, time (days), and soil temperature to achieve 10\%, 50\%, and 90\% cover; cumulative soil temperature to achieve $10 \%, 50 \%$, and $90 \%$ cover; along with actual cover and NDVI data by week were analyzed using Minitab statistical software (version 14; Minitab, State College, PA). The 12 bentgrass species and cultivars as treatments were analyzed as a randomized complete block design, with species and their cultivars as main plots using analysis of variance (ANOVA). One-way ANOVA was used to separate species (i.e., creeping bentgrass, colonial bentgrass, and velvet bentgrass) differences using 95\% confidence intervals. Least significant difference values at $\alpha=0.05$ level were computed to separate between treatments among main effects due to bentgrass species and cultivars. No serious departures from the assumptions of ANOVA were detected in homogeneity of variance or normality. Correlation coefficients $(r)$ were computed to assess the relationship among various response variables. Turf performance index (TPI) was used to categorize bentgrass species and cultivars according to their rank performance based on cover and NDVI. This nonparametric test is used to combine an overall assessment of groundcover as the number of times a bentgrass species and cultivar performed in the highest statistical grouping.

\section{Results and discussion}

Soil temperatures at the $1 / 2$ inch soil depth increased linearly at a rate of $0.21{ }^{\circ} \mathrm{C} \cdot \mathrm{d}^{-1}$ during the experimental period from 8 Apr. (planting date) until termination on 31 May 2013 (Fig. 1). Hardegree and Van Vactor (2000) reported a similar warming rate of $0.18^{\circ} \mathrm{C} \cdot \mathrm{d}^{-1}$ at a soil depth of 0.4 inch in Idaho from winter to early spring. Daily temperature averages during our study ranged from $4.7^{\circ} \mathrm{C}$ on $11 \mathrm{Apr}$. to $23.5^{\circ} \mathrm{C}$ on 30 May (Fig. 1). These soil temperature ranges represent suboptimal and optimal temperatures for cool-season turfgrass seed germination (McGinnies, 1960). The lowest recorded soil temperature $\left(4.7^{\circ} \mathrm{C}\right)$ was $\approx 4$ to $5{ }^{\circ} \mathrm{C}$ below $\mathrm{Tb}$ for germination of bentgrass species (Beard, 1979; Trudgill et al., 2000) but close to $\mathrm{Tb}$ for perennial ryegrass (Beard, 1979; Larsen and Bibby, 2005; Trudgill et al., 2000). Initial soil temperature for seedling emergence for perennial ryegrass was $9.8^{\circ} \mathrm{C}$ in all plots at day 9 after planting. Most creeping bentgrass cultivars emerged $\mathrm{l} \mathrm{d}$ after perennial ryegrass at day 10 after planting (Table 2). Velvet bentgrass cultivars emerged last on day 13 after planting at $10.4{ }^{\circ} \mathrm{C}$. Average daily soil temperatures were variable day-to-day during this early spring period, with the linear trend $\left(r^{2}\right)$ accounting for $55.3 \%$ of the total variation (Fig. 1). Soil temperature varies widely day-to-day with weather conditions, which is typical for this spring period (Hardegree and Van Vactor, 2000; Larsen and Bibby, 2005).

Slope estimates for grass cover per unit day and per unit ${ }^{\circ} \mathrm{C}$ indicate the capacity to establish over the time course from $10 \%$ to $90 \%$ grass cover (Table 2). Creeping bentgrass species averaged $6.5 \%$ grass cover per day, which was statistically better than velvet bentgrass cultivars $(5.4 \% / \mathrm{d})$ but equal to colonial bentgrass $(6.1 \% / d)$. Creeping bentgrass cultivars $13-\mathrm{M}(8.7 \% / \mathrm{d})$ and Memorial $(9.6 \% / \mathrm{d})$ were statistically equal to Barbeta perennial ryegrass $(7.8 \% / \mathrm{d})$ in their capacity to achieve faster cover from $10 \%$ to $90 \%$. Creeping bentgrass cultivars 007, Declaration, L-93, and T-1, along with all velvet bentgrass cultivars (Greenwich, SR7200 , and Villa) and Tiger II colonial bentgrass, were among the slowest to establish (less grass cover per day) over the time course from $10 \%$ to $90 \%$ grass cover. 


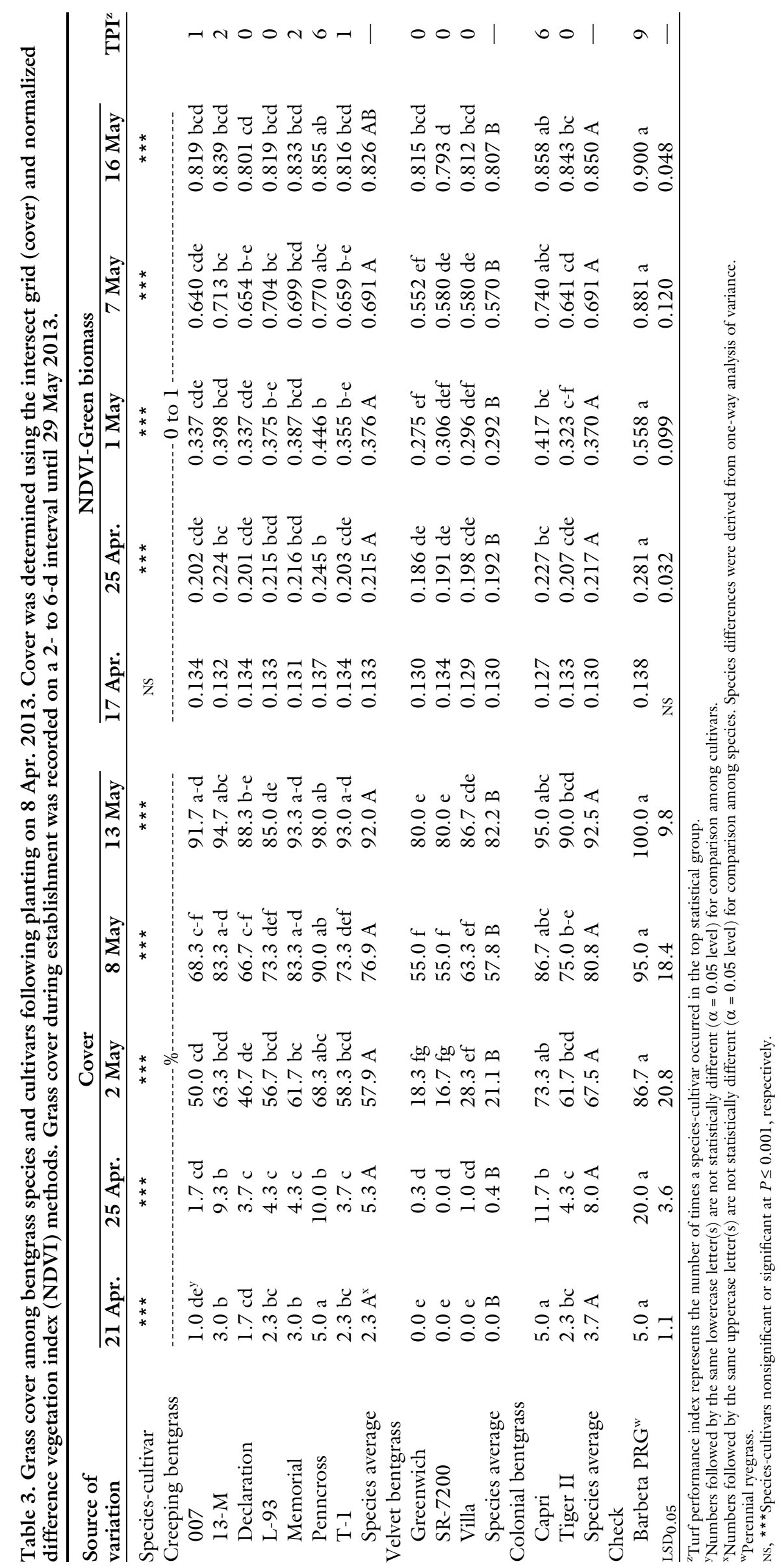


Table 4. Cumulative soil temperatures to achieve $10 \%, 50 \%$, and $90 \%$ grass cover among bentgrass species and cultivars following planting on $8 \mathrm{Apr}$. 2013. Grass cover during establishment was recorded on a 2- to 6-d interval using an intersect grid until 29 May 2013.

\begin{tabular}{|c|c|c|c|}
\hline Source of variation & $10 \%$ cover & $50 \%$ cover & $90 \%$ cover \\
\hline Species-cultivar & $* * *$ & ** & * \\
\hline \multicolumn{4}{|l|}{ Creeping bentgrass } \\
\hline 007 & $49.5 \mathrm{fg}^{\mathrm{y}}$ & $136.2 \mathrm{bcd}$ & $258.7 \mathrm{a}-\mathrm{d}$ \\
\hline $13-\mathrm{M}$ & $81.1 \mathrm{abc}$ & $137.4 \mathrm{bcd}$ & $196.8 \mathrm{~cd}$ \\
\hline Declaration & $61.8 \mathrm{def}$ & $162.0 \mathrm{ab}$ & $294.9 \mathrm{ab}$ \\
\hline L-93 & $68.2 \mathrm{cde}$ & $156.1 \mathrm{abc}$ & $269.7 \mathrm{abc}$ \\
\hline Memorial & $82.2 \mathrm{abc}$ & $138.2 \mathrm{bcd}$ & $212.2 \mathrm{bcd}$ \\
\hline Penncross & $55.5 \mathrm{efg}$ & $118.8 \mathrm{ab}$ & $194.6 \mathrm{~cd}$ \\
\hline $\mathrm{T}-1$ & 73.4 cde & $153.3 \mathrm{abc}$ & $255.3 \mathrm{a}-\mathrm{d}$ \\
\hline Species average & $67.4 \mathrm{~B}^{\mathrm{x}}$ & $143.1 \mathrm{~B}$ & $240.3 \mathrm{AB}$ \\
\hline \multicolumn{4}{|l|}{ Velvet bentgrass } \\
\hline Greenwich & $92.1 \mathrm{ab}$ & $181.7 \mathrm{a}$ & $299.5 \mathrm{a}$ \\
\hline SR-7200 & $98.1 \mathrm{a}$ & $182.5 \mathrm{a}$ & $308.9 \mathrm{a}$ \\
\hline Villa & $79.2 \mathrm{bcd}$ & $160.8 \mathrm{ab}$ & $262.8 \mathrm{a}-\mathrm{d}$ \\
\hline Species average & $89.8 \mathrm{~A}$ & $175.0 \mathrm{~A}$ & $290.4 \mathrm{~A}$ \\
\hline \multicolumn{4}{|l|}{ Colonial bentgrass } \\
\hline Capri & $61.4 \mathrm{def}$ & $120.4 \mathrm{~cd}$ & $187.7 \mathrm{~cd}$ \\
\hline Tiger II & $36.5 \mathrm{~g}$ & $117.4 \mathrm{~cd}$ & $232.2 \mathrm{a}-\mathrm{d}$ \\
\hline Species average & $49.0 \mathrm{C}$ & $118.9 \mathrm{~B}$ & $210.0 \mathrm{~B}$ \\
\hline \multicolumn{4}{|l|}{ Check } \\
\hline Barbeta PRGw & $46.6 \mathrm{fg}$ & $104.3 \mathrm{~d}$ & $168.0 \mathrm{~d}$ \\
\hline $\mathrm{LSD}_{0.05}$ & 18.6 & 39.1 & 95.0 \\
\hline \multicolumn{4}{|c|}{ 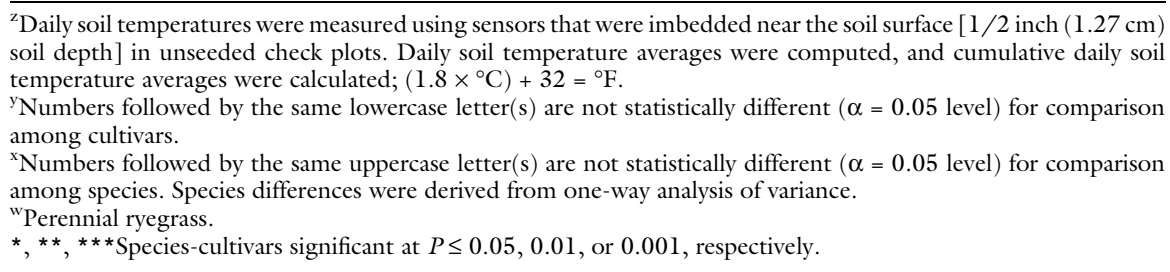 } \\
\hline
\end{tabular}

Regression slope estimates for grass cover per unit day and cover per unit ${ }^{\circ} \mathrm{C}$ were highly correlated $(r=$ $0.821, P \leq 0.001)$. Perennial ryegrass during soil warming for the period from $10 \%$ to $90 \%$ grass cover achieved the highest grass cover per unit ${ }^{\circ} \mathrm{C}$ of $53.5 \%$. Creeping bentgrass cultivars 13-M and Memorial, along with Capri colonial bentgrass, achieved statistically similar rates of increase in grass cover per unit ${ }^{\circ} \mathrm{C}$ and were comparable to perennial ryegrass (Table 2 ). Creeping bentgrass cultivar Declaration was the lowest in its capacity to increase grass cover during soil warming in the early spring period $\left(28.6 \% /{ }^{\circ} \mathrm{C}\right)$, which was about half the rate of perennial ryegrass. Similarly, all velvet bentgrass cultivars, along with some creeping bentgrass cultivars (007, L-93, and T-1) and 'Tiger II' colonial bentgrass, were statistically equal to 'Declaration' creeping bentgrass in their inability to achieve grass cover with soil warming in the early spring.
Even though bentgrass species and cultivars varied only 2 to $3 \mathrm{~d}$ in their initial seedling emergence ( $\mathrm{Ta}$ ble 2 ), days to $10 \%, 50 \%$, and $90 \%$ cover ranged from 5.3 to $10.8 \mathrm{~d}(5.5 \mathrm{~d}$ difference), 12.4 to $17.5 \mathrm{~d}$ (5.1 d difference), and 17.8 to $26.4 \mathrm{~d}(8.6$ $\mathrm{d}$ difference), respectively (Table 2 ). Colonial bentgrass cultivars averaged the fewest days to achieve $10 \%, 50 \%$, and $90 \%$ grass cover, with velvet bentgrass cultivars on average requiring more time (days) to establish $10 \%$, $50 \%$, and $90 \%$ grass cover (Table 2). Bentgrass cultivars that were statistically equivalent to perennial ryegrass in days to $90 \%$ cover $(16.4 \mathrm{~d})$ included Capri and Tiger II colonial bentgrasses and most creeping bentgrasses cultivars except Declaration and L-93. None of the three velvet bentgrass entries were comparable to perennial ryegrass. Similar results among bentgrass species and cultivars were observed in time (days) to establish to $50 \%$ grass cover.
Soil temperatures to achieve $10 \%, 50 \%$, and $90 \%$ cover are also reported in Table 2. Grass cover achieved at lower soil temperatures is beneficial for establishing in early spring with incremental soil warming as shown in Fig. 1. Perennial ryegrass achieved $10 \%, 50 \%$, and $90 \%$ grass cover at lower soil temperatures corresponding to $10.3,11.0$, and $11.7^{\circ} \mathrm{C}$, respectively (Table 2 ). Perennial ryegrass has been shown to exhibit lower $\mathrm{Tb}$ for initial germination than bentgrass species (Trudgill et al., 2000), with $\mathrm{Tb}$ for perennial ryegrass reported to be as low as $1.4^{\circ} \mathrm{C}$ (Moot et al., 2000). Moreover, perennial ryegrass has among the lowest GDD to $50 \%$ of final germination (Larsen and Bibby, 2005). Species averages indicated that velvet bentgrass entries exhibited the highest soil temperatures to achieve $10 \%, 50 \%$, and $90 \%$ cover corresponding to $11.3,12.5$, and $13.6^{\circ} \mathrm{C}$. Velvet bentgrass soil temperatures for establishment are $\approx 1.0$ to $2.0{ }^{\circ} \mathrm{C}$ higher than perennial ryegrass, and higher when compared with both creeping and colonial bentgrasses. The lowest soil temperature to achieve $90 \%$ grass cover equivalent to perennial ryegrass was ' $13-\mathrm{M}$ ' and 'Penncross' creeping bentgrasses and 'Capri' colonial bentgrass, which were almost $1.0^{\circ} \mathrm{C}$ higher than perennial ryegrass and close to $12.5^{\circ} \mathrm{C}$ soil temperature. A similar soil temperature average of $12.5^{\circ} \mathrm{C}$ - that was sufficient for $90 \%$ cover in some creeping and colonial bentgrasses - was required for velvet bentgrass to establish to only $50 \%$ grass cover (Table 2 ). Incremental differences as small as $1.0^{\circ} \mathrm{C}$ soil temperature can have significant effects on grass cover, as indicated by slope estimates (grass cover per ${ }^{\circ} \mathrm{C}$ ) shown in Table 2 .

Table 3 displays periodic cover during the establishment period, with grass cover measured using the grid intersect method and as NDVI reflectance. All plots were at least $90 \%$ cover by 21 May and $95 \%$ cover by 25 May (data not shown). At all evaluation dates, bentgrass species and cultivars were statistically significant, except for the first rating date for NDVI (17 Apr.). Correlations between grass cover and NDVI were highly correlated, especially when grass cover and NDVI measurements are compared at similar times (data not shown).

Perennial ryegrass was observed in the top statistical performance group 


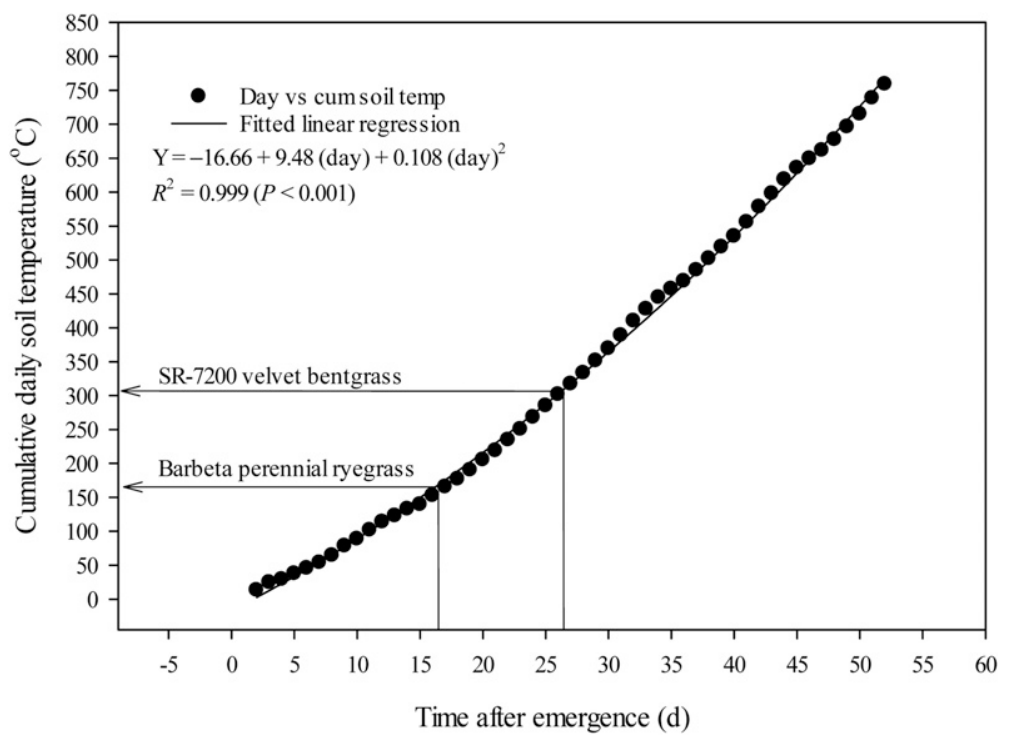

Fig. 2. Cumulative (cum) daily soil temperature (temp) average recorded during the experimental period. Soil sensors were imbedded near the soil surface $[1 / 2$ inch $(1.27-\mathrm{cm})$ soil depth] in unseeded check plots. Observed cumulative soil temperatures ranged from $2.7^{\circ} \mathrm{C}$ (day 2) to $768.3^{\circ} \mathrm{C}$ (day 52 ) following planting on 8 Apr. 2013. 'Barbeta' perennial ryegrass was the first to achieve $90 \%$ grass cover [day 16.4 (Table 2); cumulative soil temperature $=168.0{ }^{\circ} \mathrm{C}$ (Table 4)], while 'SR-7200' velvet bentgrass was the last to achieve $90 \%$ grass cover [day 26.4 (Table 2); cumulative soil temperature $=308.9{ }^{\circ} \mathrm{C}($ Table 4$\left.)\right] ;\left(1.8 \times{ }^{\circ} \mathrm{C}\right)+32={ }^{\circ} \mathrm{F}$.

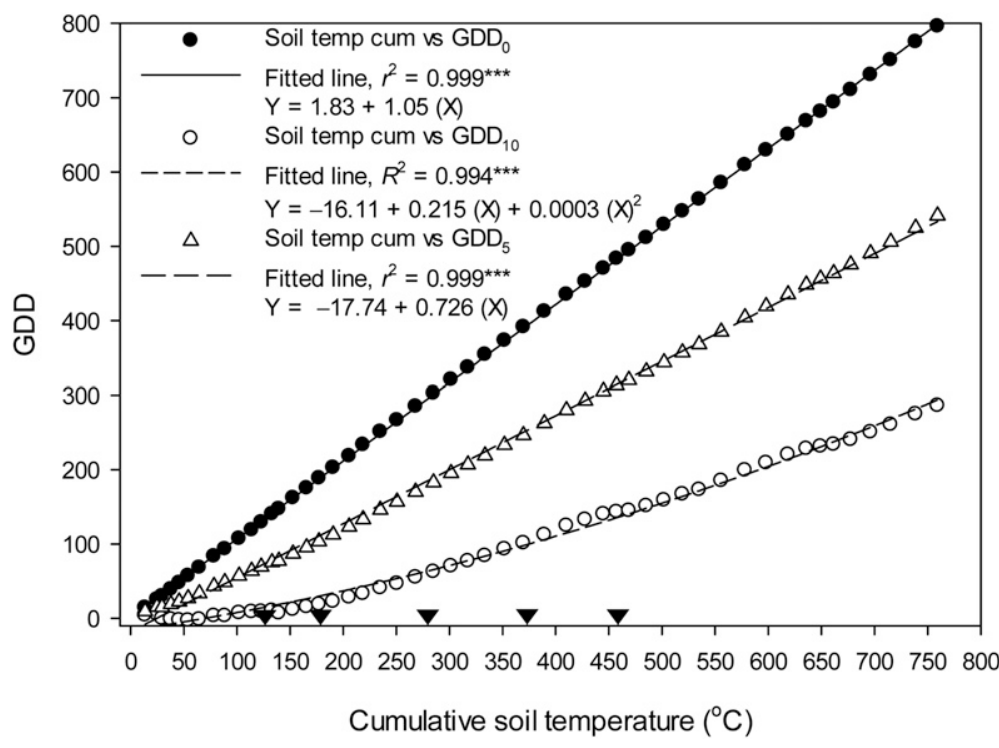

Fig. 3. Relationship between cumulative soil temperatures and growing degree day (GDD) comparing GDD base soil temperatures (temp) of 0,5 , and $10{ }^{\circ} \mathrm{C}$ with cumulative (cum) daily soil temperature average recorded during the experimental period. Soil sensors were imbedded near the soil surface [1/2-inch $(1.27-\mathrm{cm})$ soil depth] in unseeded check plots. Observed cumulative soil temperatures ranged from $2.7^{\circ} \mathrm{C}$ $\left(\mathrm{GDD}_{0}=4.7^{\circ} \mathrm{C} ; \mathrm{GDD}_{5}=-15.8^{\circ} \mathrm{C} ; \mathrm{GDD}_{10}=-16.2^{\circ} \mathrm{C}\right)$ to $768.3^{\circ} \mathrm{C}($ day 52 , $\left.\mathrm{GDD}_{0}=808.6^{\circ} \mathrm{C} ; \mathrm{GDD}_{5}=541.6^{\circ} \mathrm{C} ; \mathrm{GDD}_{10}=326.3^{\circ} \mathrm{C}\right)$ following planting on 8 Apr. 2013. Arrows indicate cumulative soil temperatures when grass cover (Table 3 ) was evaluated at 21 and $25 \mathrm{Apr}$., and 2, 8, and 13 May 2013; $\left(1.8 \times{ }^{\circ} \mathrm{C}\right)+32={ }^{\circ} \mathrm{F}$.

nine times according to the TPI for grass cover and NDVI, followed by 'Penncross' creeping bentgrass and 'Capri' colonial bentgrass with a TPI of six (Table 3). Creeping bentgrass cultivars $13-\mathrm{M}$ and Memorial were reported to be in the top statistical performance group two times, with both 007 and
T-1 creeping bentgrasses in the top statistical grouping only one time. No velvet bentgrass cultivar was ever observed to be in the top statistical performance group, along with 'Declaration' and 'L-93' creeping bentgrass and ' $\mathrm{Ti}$ ger II' colonial bentgrass (Table 3 ).

Heineck et al. (2018) found 'Declaration' creeping bentgrass to have among the best seed germination rates for early spring laboratory test temperatures (mid-April) in their simulation test temperature of $7.0^{\circ} \mathrm{C}$. Our field study indicated that 'Declaration' was a poor performer, requiring higher soil temperatures to achieve $90 \%$ grass cover during soil warming in early spring along with the lowest grass cover per day $(4.5 \%$ / d) and the lowest grass cover per ${ }^{\circ} \mathrm{C}$ $\left(28.6 \% /{ }^{\circ} \mathrm{C}\right)$ (Table 2$)$. Alternatively, 'Memorial' creeping bentgrass in our field study performed well in terms of grass cover (Table 3 ), higher grass cover per day, and higher grass cover per ${ }^{\circ} \mathrm{C}$ (Table 2 ). In laboratory simulation tests Heineck et al. (2018) concluded 'Memorial' should not be recommended for planting in early spring because of poor germination characteristics at $7.0^{\circ} \mathrm{C}$. These results underscore the need to validate, in the field, simulation test temperatures conducted in the laboratory, as suggested by the work of Hardegree and Van Vactor (2000) because of the numerous biological, chemical, and physiological factors affecting establishment in the field (Egli and TeKrony, 1996; Hegarty, 1973; Weaich et al., 1996). A major shortcoming of this current field experiment is the study was not replicated in other years, and only one planting date was used-whereas multiple years of testing, along with multiple planting dates and locations (soil types), can provide more robust and reliable results and conclusions (Hardegree and Van Vactor, 2000). In addition, we did not evaluate different seed lots of bentgrass species and cultivars. Variation in seed lots are known to explain, in part, seed vigor and quality between cultivars (Larsen and Bibby, 2004; Liu et al., 2001). The use of more than one seed lot per cultivar may provide more reliable cultivar differences and results.

Cumulative soil temperature averages were also calculated and analyzed (Table 4). Cumulative soil temperature followed a near linear trend with days (Fig. 2). Perennial ryegrass exhibited among the lowest 
Table 5. Selected correlation values for seed weight, percent grass cover per day $\left(\right.$ Cover/d), and percent grass cover per ${ }^{\circ} \mathrm{C}\left(\mathrm{Cover} /{ }^{\circ} \mathrm{C}\right)$ with cumulative soil temperatures to achieve $10 \%, 50 \%$, and $90 \%$ cover for bentgrass species and cultivars $(n=39)$. Grass cover among bentgrass species and cultivars was determined using the intersect grid following planting on $8 \mathrm{Apr} .2013$ and recorded on a 2- to 6-d interval until 29 May 2013.

\begin{tabular}{lccc}
\hline Cumulative soil temp at specific grass cover $^{\mathrm{z}}$ & Seed wt $^{\mathrm{y}}$ & Cover $/ \mathrm{d}$ & Cover $/{ }^{\circ} \mathbf{C}$ \\
\hline & $-0.300 \mathrm{NS}$ & $0.126 \mathrm{NS}$ & $0.159 \mathrm{NS}$ \\
$10 \%$ & $-0.193 \mathrm{NS}$ & $-0.485^{* *}$ & $-0.466^{* *}$ \\
$50 \%$ & $-0.055 \mathrm{NS}$ & $-0.672^{* * *}$ & $-0.688^{* *}$ \\
\hline $0 \%$ & &
\end{tabular}

${ }^{\mathrm{z} C u m u l a t i v e ~ s o i l ~ t e m p e r a t u r e s ~ d e r i v e d ~ f r o m ~ c u r v e ~ f i t t i n g ~ s o i l ~ t e m p e r a t u r e s ~ w i t h ~ p e r c e n t ~ c o v e r ~ t o ~ e s t a b l i s h ~} 10 \%$, $50 \%$, and $90 \%$ cover. These cumulative soil temperatures for bentgrass species and cultivars at $10 \%, 50 \%$, and $90 \%$ cover are reported in Table 4.

${ }^{y}$ Average weight of three replicates of 100 seeds.

NS, ${ }^{* *},{ }^{* *}$ Nonsignificant at $P \leq 0.05$ or significant at $P \leq 0.01$ or 0.001 , respectively.

cumulative soil temperatures to establish to $10 \%, 50 \%$, and $90 \%$ grass cover (Table 4). Colonial bentgrass was consistently among the lowest in cumulative soil temperatures, with velvet bentgrass cultivars requiring statistically higher cumulative soil temperatures to establish (Table 4). Bentgrass cultivars that were able to establish $50 \%$ to $90 \%$ grass cover at statistically equivalent cumulative soil temperatures to perennial ryegrass included Capri and Tiger II colonial bentgrasses, as well as $007,13-\mathrm{M}$, and Memorial creeping bentgrasses (Table 4).

Cumulative soil temperatures captured at least $99 \%$ of the covariation in $\mathrm{GDD}_{0}, \mathrm{GDD}_{5}$, and $\mathrm{GDD}_{10}$ (Fig. 3). Linear regression models reported in Fig. 3 allow cumulative soil temperatures from Table 4 to be converted to $\mathrm{GDD}_{0}, \mathrm{GDD}_{5}$, and $\mathrm{GDD}_{10}$ for bentgrass species and cultivars. Base temperatures to initiate seed germination can vary with the species and cultivar (Beard, 1979; Larsen and Bibby, 2005; Trudgill et al., 2000). Therefore, adjusting cumulative soil temperatures to predict GDD using different $\mathrm{Tb}$ are presented here for this single planting date.

The rate of cover per unit day and per unit ${ }^{\circ} \mathrm{C}$ increased with decreasing cumulative soil temperature during soil warming in early spring (Table 5). Bentgrass species and cultivars to establish cover from $50 \%$ to 90\% were closely associated with the capacity of bentgrass species to establish cover at lower cumulative soil temperatures (Table 4). Fewer days to establish cover (i.e., faster establishment) were generally associated with lower cumulative soil temperatures. The capacity of bentgrass species to establish cover under lower cumulative soil temperatures during early spring (Figs. 1 and 2) were associated with faster rates of establishment.

During establishment, seed vigor and seed quality are more closely related to the early stages of establishment (seed germination and emergence). Alternatively, at later stages during development of mature plants and the formation of dense turf, establishment is under genetic control. A positive relationship is often observed between seed weight or size and laboratory seed germination percentages (Brown, 1977; Larsen and Andreasen, 2004; Veronesi et al., 1983). It is acknowledged that within a species, larger seeds are more vigorous but larger seeds have lower seed counts per unit area when planted by weight in the field. Therefore, seed size and its relationship to field emergence and establishment is more complicated. In our study, bentgrass species and cultivars of larger seed size or weight (Table 1) were positively correlated with greater establishment cover during early stages of establishment (Table 6). For example, $r$-values ranged from $0.462(P=0.01, \mathrm{n}=39)$ measured on 21 Apr. to $0.254(P>$ 0.05 ) on 13 May (Table 6). Similarly, larger seed weights were associated with fewer days to $10 \%$ cover $(r=$ $-0.376, P=0.024, \mathrm{n}=39)$, but seed size and weight were uncorrelated with later stages of establishment (time to $50 \%$ and $90 \%$ cover). Conversely, Christians et al. (1979) reported higher seed counts (lighter seed weights) among kentucky bluegrass cultivars to establish stands more rapidly than cultivars with fewer seeds per gram (heavier seed weights), when seeded at the same rate of $73 \mathrm{~kg} \cdot \mathrm{ha}^{-1}$. They also found that differences due to seeding rate, comparing seed weight per unit area vs. seed count per unit area, exist only during the initial stages of establishment (within 6 months after planting). Therefore, in our study, seeding rates were standardized to deliver the same live seed count per unit area $\left(31,000\right.$ seeds $\left./ \mathrm{m}^{2}\right)$, using different seeding rates (Table 1 ) to account for seed size differences and their potential impact on cover during the early stages of establishment.

Slope estimates measured as grass cover per day and grass cover per ${ }^{\circ} \mathrm{C}$ were positively correlated with cover measured using the intersect grid and NDVI reflectance (Table $6)$. Predicted time (days) to $10 \%$, $50 \%$, and $90 \%$ grass cover were inversely related to cover and NDVI, indicating shorter intervals (days) were associated with greater cover and NDVI reflectance. Days to $50 \%$ and $90 \%$ cover were more strongly correlated with cover and NDVI measured during later stages of establishment (Table 6).

Overall, all velvet bentgrass cultivars evaluated required higher soil temperatures $\left(13.6^{\circ} \mathrm{C}\right)$ to establish to $90 \%$ cover during soil warming in early spring. Velvet bentgrasses were slow to establish during this period, requiring $26 \mathrm{~d}$ after seedling emergence to establish to $90 \%$ cover. 'Barbeta' perennial ryegrass was able to establish $90 \%$ cover at $16 \mathrm{~d}$ after seedling emergence, which corresponded to soil temperatures of $11.6^{\circ} \mathrm{C}$. Creeping bentgrass cultivars 007, 13-M, and Memorial, along with colonial bentgrass cultivars Capri and Tiger II, were statistically equal to Barbeta perennial ryegrass in their capacity after seedling emergence to achieve faster cover at lower soil temperatures. Bentgrass species and cultivars varied only 2 to $3 \mathrm{~d}$ in their initial seedling emergence, while time (days) varied among bentgrasses from $5.5 \mathrm{~d}$ to $10 \%$ cover to $8.6 \mathrm{~d}$ to $90 \%$ cover. Heavier (larger) bentgrass seed was generally associated with faster cover during the early stages of establishment (to $10 \%$ cover), but seed size was uncorrelated with establishment during later stages from $50 \%$ to $90 \%$ cover. Most bentgrass species and cultivars emerged at $\approx 10{ }^{\circ} \mathrm{C}$ soil temperature. Therefore, seeding as early as possible when soil temperatures are $10{ }^{\circ} \mathrm{C}$ and higher could be 
Table 6. Selected correlation values for bentgrass species and cultivars $(n=39)$ with grass cover following planting on 8 Apr. 2013. Grass cover among bentgrass species and cultivars was determined on a 2- to 6-d interval until 29 May 2013.

\begin{tabular}{|c|c|c|c|c|c|c|}
\hline Cover & Seed $w^{\mathrm{z}}$ & Cover $/ \mathrm{d}$ & Cover $/{ }^{\circ} \mathrm{C}$ & Time to $10 \%$ cover & Time to $50 \%$ cover & Time to $90 \%$ cover \\
\hline \multicolumn{7}{|l|}{ Cover $^{y}$} \\
\hline 21 Apr. & 0.462 ** & $0.492 * * *$ & $0.551 * * *$ & -0.432 ** & $-0.638 * * *$ & $-0.612 * * *$ \\
\hline 25 Apr. & $0.372 *$ & 0.425 ** & $0.603 * * *$ & $-0.438^{* *}$ & $-0.663^{* * *}$ & $-0.635^{* * *}$ \\
\hline 2 May & $0.400^{*}$ & 0.496 *** & 0.490 ** & $-0.550 * * *$ & -0.888 *** & $-0.815^{* * *}$ \\
\hline 8 May & $0.269 \mathrm{NS}$ & $0.662 * * *$ & $0.619 * * *$ & $-0.341^{*}$ & $-0.907 * * *$ & $-0.928 * * *$ \\
\hline 13 May & $0.254 \mathrm{NS}$ & $0.510 * * *$ & $0.487 * *$ & $-0.393^{*}$ & -0.870 *** & $-0.869 * * *$ \\
\hline 17 Apr. & $0.073 \mathrm{NS}$ & $0.058 \mathrm{NS}$ & $0.034 \mathrm{NS}$ & $-0.270 \mathrm{NS}$ & $-0.344^{*}$ & $-0.231 \mathrm{NS}$ \\
\hline 25 Apr. & $0.168 \mathrm{NS}$ & $0.489 * *$ & $0.618 * * *$ & $-0.402^{*}$ & $-0.757 * * *$ & $-0.726 * * *$ \\
\hline 1 May & $0.272 \mathrm{NS}$ & 0.595 *** & $0.696^{* * *}$ & $-0.289 \mathrm{NS}$ & $-0.784^{* * *}$ & $-0.813^{* * *}$ \\
\hline 7 May & $0.363^{*}$ & $0.603 * * *$ & $0.643^{* * *}$ & $-0.293 \mathrm{NS}$ & $-0.796^{* * *}$ & $-0.834^{* * *}$ \\
\hline 16 May & $0.098 \mathrm{NS}$ & $0.537 * * *$ & $0.647 * * *$ & $-0.276 \mathrm{NS}$ & $-0.734^{* * *}$ & $-0.797 * * *$ \\
\hline
\end{tabular}

${ }^{\mathrm{z}}$ Average weight of three replicates of 100 seeds.

${ }^{\mathrm{y}}$ Intersect grid was used to determine grass cover.

${ }^{x}$ Turf biomass measured by normalized difference vegetation index (NDVI) method.

NS, ${ }^{*},{ }^{*},{ }^{* *}$ Nonsignificant at $P \leq 0.05$ or significant at $P \leq 0.05,0.01$, or 0.001 , respectively.

recommended for bentgrass species and cultivars that have been field-evaluated for superior cold-temperature germination and emergence characteristics. Future research should focus on soil temperature and seed establishment vigor using multiple planting sites and seeding dates.

\section{Literature cited}

Argerich, C.A., K.J. Bradford, and F.M. Ashton. 1990. Influence of seed vigor and preplant herbicides on emergence, growth, and yield of tomato. HortScience 25:288291, doi: 10.21273/HORTSCI.25.3.288.

Beard, J.B. 1973. Turfgrass science and culture. Prentice Hall, Englewood Cliffs, NJ.

Beard, J.B. 1979. Minimum temperature requirements for seed germination of turfgrasses. Proc. Texas Turfgrass Conf. College Station, 3-5 Dec. 1979. p. 8286.

Brown, K.R. 1977. Parent seed weight, plant growth, and seeding in 'Grassland Tama' westerwolds ryegrass. N. Z. J. Exp. Agr. 5:143-146, doi: 10.1080/03015521. 1977.10425953.

Burris, J.S. 1976. Seed/seedling vigor and field performance. J. Seed Technol. $1: 158-174$.

Christians, N.E., J.F. Wilkinson, and D.P. Martin. 1979. Variations in the number of seeds per unit weight among turfgrass cultivars. Agron. J. 71:415-419, doi: 10.2134/ agronj1979.00021962007100030008x.

Egli, D.B. and D.M. TeKrony. 1996. Seedbed conditions and prediction of field emergence of soybean seed. J. Prod. Agr. 9:365-370, doi: 10.2134/jpal996.0365.

Frank, K.W., R.E. Gaussoin, T.P. Riordan, and E.D. Miltner. 1998. Date of planting effects on seeded turf-type buffalograss. Crop Sci. 38:1210-1213, doi: 10.2135/ cropscil998.0011183X003800050016x.

Happ, K., M.B. McDonald, and T.K. Danneberger. 1993. Vigor testing in perennial ryegrass (Lolium perenne L.) seeds. Seed Sci. Technol. 21:375-381.

Hardegree, S.P. and S. Van Vactor. 1999. Predicting germination response of four cool-season range grasses to field-variable temperature regimes. Environ. Exp. Bot. 41:209-217, doi: 10.1016/S00988472(99)00004-0.

Hardegree, S.P. and S. Van Vactor. 2000. Germination and emergence of primed seeds under field and simulated-field temperature regimes. Ann. Bot. 85:379390, doi: 10.1006/anbo.1999.1076.

He, J.Y., J.T. Wang, X.M. Bai, Q. Dong, and Y.W. Lu. 2013. Effects of temperature on seed germination characteristics of eight wild Poa germplasm. Pratacult. Sci. 30:383-389.

Hegarty, T.W. 1973. Temperature relations of germination in the field, p. 411432. In: W. Heydecker (ed.). Seed ecology. Butterworths, London, UK.

Heineck, G.C., S.J. Bauer, M. Cavanaugh, A. Hollman, E. Watkins, and B.P. Horgan. 2018. Variability in creeping bentgrass cultivar germinability as influenced by cold temperatures. Crop Forage Turfgrass Mgt. 5:1-7, doi: 10.2134/cftm2018.07.0054.

Jiang, Y. 2008. Identification of turfgrass stress utilizing spectral reflectance, p.
547-556. In: M. Pessarakli (ed.). Handbook of turfgrass management and physiology. CRC Press, Boca Raton, FL. doi: 10.1201/9781420006483.ch32.

Johnsen, A.R., B.P. Horgan, B.S. Hulke, and V. Cline. 2009. Evaluation of remote sensing to measure plant stress in creeping bentgrass (Agrostis stolonifera L.) fairways. Crop Sci. 49:2261-2274, doi: 10.2135/cropsci2008.09.0544.

Larsen, S.U. and C. Andreasen. 2004. Light and heavy turfgrass seeds differ in germination percentage and mean germination thermal time. Crop Sci. 44:17101720, doi: 10.2135/cropsci2004.1710.

Larsen, S.U. and B.M. Bibby. 2004. Use of germination curves to describe variation in germination characteristics in three turfgrass species. Crop Sci. 44:891-899, doi: 10.2135/cropsci2004.8910.

Larsen, S.U. and B.M. Bibby. 2005. Differences in thermal time requirement for germination of three turfgrass species. Crop Sci. 45:2030-2037, doi: 10.2135/ cropsci2004.0731.

Larsen, S.U., C. Andreasen, and P. Kristoffersen. 2004. Differential sowing time of turfgrass species affects the establishment of mixtures. Crop Sci. 44:13151322, doi: 10.2135/cropsci2004.1315.

Laycock, R.W. and J.P. Shildrick. 1979. Multi-centre trials of turfgrass cultivars in the U.K. No. 1. Lolium perenne (perennial ryegrass), (1974-8). J. Sports Turf Res. Inst. 55:7-35.

Lee, H., D.J. Bremer, K. Su, and S.J. Keeley. 2011. Relationships between normalized difference vegetation index and visual quality in turfgrasses: Effects of 
mowing height. Crop Sci. 51:323-332, doi: $10.2135 /$ cropsci2010.05.0296.

Liu, C., J.J. Camberato, S.B. Martin, and A.V. Turner. 2001. Rough bluegrass germination varies with temperature and cultivar/seed lot. HortScience 36:153-156, doi: 10.21273/HORTSCI.36.1.153.

McGinnies, W.J. 1960. Effects of moisture stress and temperature on germination of six range grasses. Agron. J. 52:159-162, doi: 10.2134/agronj1960. $00021962005200030012 \mathrm{x}$.

Moot, D.L., W.R. Scott, A.M. Roy, and A.C. Nicholls. 2000. Base temperature and thermal time requirements for germination and emergence of temperate pasture species. N. Z. J. Agr. Res. 43:15-25, doi: 10.1080/00288233.2000.9513404.

Murphy, J.A., H. Samaranayake, T.J. Lawson, J.A. Honig, and S. Hart. 2005. Seeding date and cultivars impact on establishment of bentgrass in soil containing annual bluegrass seed. Intl. Turfgrass Soc. Res. J. 10:410-415.

Patton, A.J., G.A. Hardebeck, D.W. Williams, and Z.J. Reicher. 2004. Establishment of bermudagrass and zoysiagrass by seed. Crop Sci. 44:2160-2167, doi: 10.2135/cropsci2004.2160.

Pollock, B.M. 1972. Effects of environment after sowing on viability, p. 150171. In: E.H. Roberts (ed.). Viability of seeds. Syracuse Univ. Press, Syracuse, NY. doi: 10.1007/978-94-009-5685-8_6.

Powell, A.A. 1988. Seed vigor and field establishment. Adv. Res. Technol. Seeds. 11:29-61.
Scott, S.J. and R.A. Jones. 1985. Cold tolerance in tomato. I. Seed germination and early seedling growth of Lycopersicon esculentum. Physiol. Plant. 65:487-492, doi: 10.1111/j.1399-3054.1985.tb08678.x.

Shahba, M.A. and Y.L. Qian. 2008. Effect of seeding date, seeding rate, and seed treatments on saltgrass seed germination and establishment. Crop Sci. 48:2453-2458, doi: 10.2135/cropsci2008.02.0076.

Snapp, S., R. Price, and M. Morton. 2008. Seed priming of winter annual cover crops improves germination and emergence. Agron. J. 100:1506-1510, doi: 10.2134 /agronj2008.0045N.

Steiner, J.J., D.F. Grabe, and M. Tulo. 1989. Single and multiple vigor tests for predicting seedling emergence of wheat. Crop Sci. 29:782-786, doi: 10.2135/ cropscil989.0011183X002900030049x.

Trawatha, S.E., J.J. Steiner, and K.J. Bradford. 1990. Laboratory vigor tests used to predict pepper seedling field emergence performance. Crop Sci. 30:713-717, doi: 10.2135/cropscil 990. 0011183 X003000030048x.

Trudgill, D.L., G.R. Squire, and K. Thompson. 2000. A thermal time basis for comparing the germination requirements of some British herbaceous plants. New Phytol. 145:107-114, doi: 10.1046/j.14698137.2000.00554.x.

Unruh, J.B., R.E. Gaussoin, and S.C. Weist. 1996. Basal growth temperatures and growth rate constants of warm-season turfgrass species. Crop Sci. 36:997-999, doi: 10.2135/ cropscil996.0011183X0036000400030x.
Veronesi, F., F. Damiani, S. Grando, and M. Falcinelli. 1983. The influence of seed weight on establishment and productivity in the first year in Lolium perenne L. Genet. Agrar. 37:391-402.

Weaich, K., K.L. Bristow, and K.L. Cass. 1996. Simulating maize emergence using soil and climatic data. Agron. J. 88:667-674, doi: 10.2134/agronj1996.00021962008800 040028x.

Wright, D.L., R.E. Blazer, and J.M. Woodruff. 1978. Seedling emergence as related to temperature and moisture tension. Agron. J. 70:709-712, doi: 10.2134/ agronj1978.00021962007000050001x.

Yamamoto, I., A.J. Turgeon, and J.M. Duich. 1997a. Field emergence of solid matrix primed turfgrasses. Crop Sci. 37:220-225, doi: 10.2135/cropscil997.0011183X003700010038x.

Yamamoto, I., A.J. Turgeon, and J.M. Duich. 1997b. Seedling emergence and growth of solid matrix primed kentucky bluegrass seed. Crop Sci. 37:225-229, doi: 10.2135/cropscil997.0011183X003700010039x.

Young, J.A. and R.A. Evans. 1982. Temperature profiles of cool season grasses. U.S. Dept. Agr., Agr. Res. Serv., Western Reg. ARR-W-27.

Zhang, H., C.R. McGill, L.J. Irving, P.D. Kemp, and D. Zhou. 2013. A modified thermal time model to predict germination rate of ryegrass and tall fescue at constant temperatures. Crop Sci. 53:240-249, doi: $10.2135 /$ cropsci2012.02.0085. 